\title{
高等学校におけるGISを活用した空間処理能力の育成
}

-SPP事業の実践を通じてー

\section{Development of Geo-spatial Information Processing Ability:}

\author{
A Case of Science Partnership Program in a High School
}

\author{
福井 朋美* \\ Tomomi FUKUI*
}

\section{I . SPP(サイエンス・パートナーシップ・プロ ジェクト)事業とは}

2002 年度から文部科学省で実施してきた $\operatorname{SPP}($ サインス・パートナーシップ・プロジェ クト)事業は, 文部科学省の「次代を担う若者へ の理数教育の拡充」施策の一環として, 小・中高 等学校と大学・科学館等の連携により, 児童生徒 の科学技術, 理科・数学 (算数)に関する興味・関 心と知的探究心等を育成することを目的とする事 業である。

このプロジェクトの中の「講座型学習活動」 は, 大学・科学館等の研究者, 技術者, 展示解説 者を講師として, 科学技術, 理科・数学(算数)に 関する観察・実験・実習等の体験的 · 問題解決的 な活動を中心とした学習活動を行う企画を支援す るものである。そのため, これは高等学校地理に おけるGIS(地理情報システム)の導入, 実践にお いて有効な機会となる。2008年度, 本プロジェク 卜に採択された北海道札幌北高等学校では, GIS を活用した研究活動を積極的に行っている北海道 大学大学院文学研究科の橋本雄一研究室と連携し て, 学習活動を行った。

本校における高大連携事業でねらいとするの は, 近年の地理空間情報高度活用社会の推進施 策を受けて，空間的思考力・認識力を身につける こと, あるいは重要性を認識する人材を育てるこ とである。本実践では，GISがもつ空間処理技術 が, 地理分野のみならず，社会における広範な分 野において必要とされている有効な技術であるこ とを強調する。
従来の高校教育ではなく, 高大連携だからこそ 可能となる上記のような取組の枠組みが構築でき れば, 中等教育の現場でも, 今後GISに関する技 術を, 地理分野に限定することなく普及させるこ とが可能となる。さらに, この取り組みは, 地理 分野における空間認識能力や空間分析能力の重要 性を強調する機会となり, 日本において地理教育 を軽視しつつある動きに対して, 地理教育の重要 性を見直す機会になることが期待できる。

本校は, 2002年度から2004年度までの 3 年間指 定を受けたSSH（スーパー・サイエンス・ハイス クール)事業の一環としてGISを導入しており， 日本地図センターのSchool GISやフリーソフト MANDARAを活用した実績がある。今回導入し たESRI社製ArcView Ver.9.2は，現在大学や民 間企業などにおいて大きなシェアを占めるソフト ウェアであり, 将来, 進学先や就職先で扱う機会 が多いと考えられる。そのため, これを用いた実 習は，実社会と結びついた高い教育効果が得られ ると期待できる。

\section{II . 実施内容}

本講座に参加した生徒は, 本校において地理 を選択している 2 年生と 3 年生であり, 実施期間 の2008年 8 月 $5 \sim 7$ 日における各日の参加者は, 1 日目は 4 名, 2 日目は 6 名, 3 日目は 8 名で, 3 日間でのべ18名であった。この期間は本校の夏 期休業中ではあるが，部活動の合宿のピークにあ たったため, 当初期待した人数よりもかなり少な かった。しかし, 全員が一台ずつのパソコンを使

*北海道札幌北高等学校 / Hokkaido Sapporo Kita High School 
用することができたため，限られたパソコン台数 に扮いて行う本実習では良好な環境を生徒に提供 することができた。3日間の講座期間中，GIS操 作の指導で北海道大学大学院文学研究科博士課程 の川村真也氏の協力を受けた。なお, 講座の内容 は下記の通りである。

\section{1. 基礎知識と技術の習得 ( 1 日目)}

1 日目 ( 8 月 5 日)の午前は, 橋本准教授による 講義を実施した。この中で地理学だけではなく, 様々な分野でGISが活用されていることや，フ リーソフトを活用した事例などが紹介され，生徒 の興味関心が高まった。

午後は, ArcViewを用いて, 翌日の実習に向 けて, 必要な基礎的な操作などの学習を行った。 ここでは, 各自が今後も作業が可能なように, 操作マニュアルを作りながら作業をすすめるよう に指示した。この日指導した操作は，(1)数值情 報25000の地図表示と道路・鉄道・川・行政界の 色分け操作などを通じて, シェープファイルの取 得・表示の方法を習得すること，(2) 店舗の分布 を札幌市の地図上にのせるため, i タウンペー ジからアドレスマッチングをして, Excelによる デー夕作成を行うことの 2 点である。

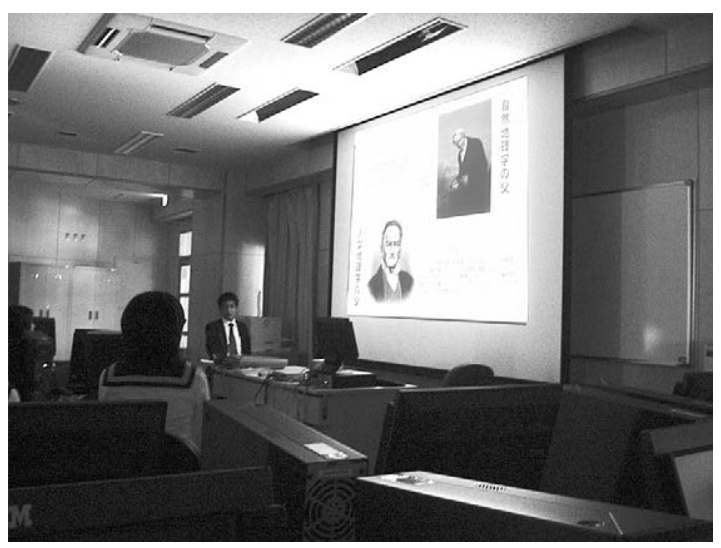

写真 1 橋本准教授による講義「地理空間情報が拓 く未来」

\section{2. 地域分析の実践 ( 2 日目)}

2 日目 (8月 6 日)は, GISを活用して地域分析 の実習を行った。この実習の課題は, 日本の高 度経済成長期以降に発展した商業・サービス業の
新業種を取り上げ，それらの都市内部における立 地戦略についてGISを援用して空間的な考察を行 うこととした。当日は, 橋本准教授による地理学 の基礎的な立地分析に関する講義が30分行われ， その後，実習で扱う業種と生徒による分担を決め た。

日本において高度経済成長期以降に発展した 商業・サービ久業を年代別に整理すると，1970年 代にはじまり急成長を遂げた業種として「ファ ミリーレストラン」・「ハンバーガーショップ」・ 「コーヒー専門店」, 1980年代に急成長した業種 として「レンタルビデオ店」，1990年代に急成長 した業種として「携带ショップ」が挙げられる。 そこで本実習では，これらの業種を対象として， 2008年 8 月時点での札幌市における店舗立地を チェーンごとに解明し, その違いから企業の立地 戦略について考察を行った。なお, これら 5 業種 を各生徒に割り振り，2 人で 1 業種の分析に取り 組むようにした。

午前中は，店舗の位置情報を用いてGISによ り地図化する作業を行った。作業では，まずグ ループごとにi タウンページのWebサイトで対 象となる業種の店舗を検索し，そこに記されて いる店舗名，住所，チェーン名称などのデー夕を EXCELに入力してCSV形式で保存した。次に， 東京大学空間情報センターのWebサイトにある CSVアドレスマッチングサービスを利用して, このEXCELデータの住所を経緯度座標に変換し た。さらにArcViewのツールであるArcMapで, 経緯度座標に変換したデー夕を読み込んで地図化 を行った。

2 日目午後の作業は，翌日のプレゼンテーショ ンに向けて，ArcViewによる空間分析の実習を 次のように進めた。(1) 国土数值情報(空間デー夕 基盤）を用いて，札幌市の市区境界，鉄道，地下 鉄などの地図化を行う。(2) 総務省Webサイトに ある統計GISプラザから，2005年国勢調査データ (小地域)の人口データをダウンロードし, 地図 化する。（3）これらの地図に, 午前中に作成した チェーン別店舗分布図を重ね合わせて表示する。

(4) 各店から $500 \mathrm{~m}$ ごとのバッファを作成し，その 中の人口を算出して地図化する。 


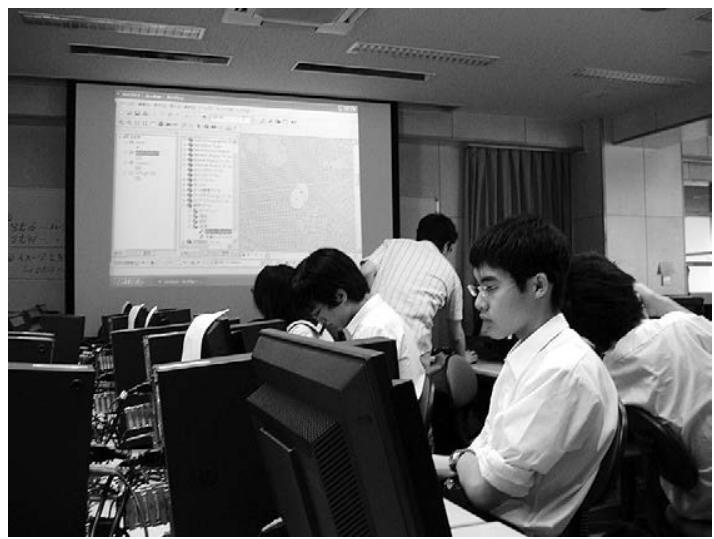

写真 2 GISの作業(バッファ作成)

これら作業の後, 店舗分布の特徵, 店舗分布と 人口との関わり, チェーンごとの店埔分布の共通 性と独自性の考察などを, 発表に盛り込むように 指導した。また，チェーン間の分布の差異に関す る考察では, 店舗の周辺人口(バッファ内の人口 の合計值)を検討するように助言を行った。

\section{3. 分析結果のプレゼンテーション( 3 日目)}

3 日目の午前中は, 地域分析作業の続きと, 発表資料の作成を行った。午後はパワーポイン トによる10分のプレゼンテーションをグループ ごとに実施した。発表の記録は, 北海道大学の e-learningコンテンツ作成システムを用い, 発表 者の画像とパワーポイント画面の両方を同時に 表示して, 自動的に発表を再生できるWeb用コ ンテンツを作成した。発表後には, 参加者全員で ディスカッションを行った。

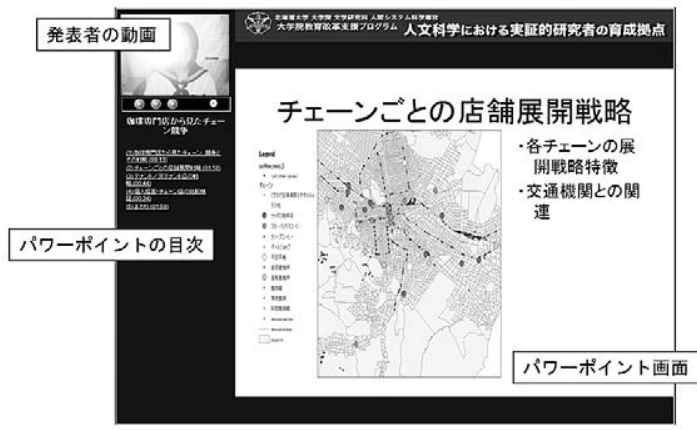

写真 3 受講生が作成したe-learning用コンテンッ

\section{III. 実習の成果}

\section{1. プレゼンテーションの内容}

生徒によるプレゼンテーションとしては, 「Softbank からみた札幌のチェーン競争と都市構 造」,「レンタルビデオ店からみたチェーン競争 と都市構造」,「珈琲専門店から見たチェーン競争 とその戦略」「「フミレスとハンバーガー店から みたチェーン競争と都市構造」の 4 題目が行われ た。これらの内容は以下の通りである。

まず，「Softbank からみた札幌のチェーン競争 と都市構造」では, 近年のSoftbankの純増 1 位の 背景には何があるかという観点で考察が進められ

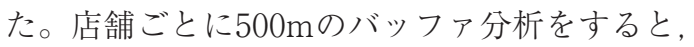
Softbankの店舗はバッファ人口が少ない北区を中 心に出店しているという特徴があった。この北区 は，札幌市中で中央区に次いで昼間人口が多いこ とから, Softbankの出店増は, 昼間人口の多い地 域への出店に力を入れるといった立地戦略が功を 奏したという結論が得られた。

次に,「レンタルビデオ店からみたチェーン競 争と都市構造」では, レンタルビデオ店が鉄道な どの沿線に分布して通勤・通学者をターゲットに していることや，人口分布との相関が小さいこと が明らかになった。また，企業分布との相関につ いても検討し，極めて企業数の多い地区には，レ ンタルビデオ店も多く立地していることがわかっ た。さらに, 本発表では, 各チェーン店の立地戦 略についてホームページなどを参考に考察を行っ た。

「珈琲専門店から見たチェーン競争とその戦 略」では，いずれの店舗も地下鉄やJRなどの交 通機関との関連があることがわかった。また，住 所デー夕などの入力作業の際に, 店舗の出店形 態にはテナントを利用するタイプと, 利用しない タイプの 2 種類に分けられると考えられた。そこ で, この 2 種類に店舗を分けて検討すると, テナ ントを利用するタイプの出店形態をとるのは, ほ とんどがチェーン店であり, 交通機関と隣接して いない場合は，デパートなどの大型店を利用した 形態をとっていることが指摘できた。また，テナ ントを利用していない店舗は, 個人経営店舗であ ることも判明した。

最後に,「ファミレスとハンバーガー店からみ 
たチェーン競争と都市構造」では，ファミリー レストランもハンバーガーショップも札幌中心部 に集中していることが明らかになった。また，店 舗を中心とした $500 \mathrm{~m}$ バッファの人口をみると， 人口が多い場所への出店が顕著であり, 地下鉄, JRの他, 幹線道路 (環状線·石山通・高速道路) の沿線へと店舗が展開していることもわかった。

\section{2 . 成果の分析}

まず，ArcViewを活用した地図作成では，ほ とんどの生徒が今回指導した店舗分布の地図化, 人口との相関分析, $500 \mathrm{~m}$ バッファの作成，バッ ファと人ロデータとのオーバーレイなどの作業 を行うことができた。店舗分布などを地図上で表 現することで，様々な分析の糸口を見出すことが でき，考察にも梁まりがみえた。例えば，交通網 との関連性はどうか, 企業数との関連はどうかな ど，実習期間にもう少しゆとりがあれば，生徒は さらに様々な情報を収集して考察を深めることが できたと感じた。さらに，分布の特徴と企業の意 志決定の関連性をみるために, 企業コンセプトや 戦略について，Webサイトを閲覧するなど，興 味の広がりを感じ取れる発表もあった。また，地 図に分布形態を示しただけでは判断できないテナ ント出店などに関わる考察もみられた。このよう な視点は, 自分達でデータ入力作業をしたからこ そ，気づくことができた好例である。以上のこと から, GISは, 高校生に課題発見や課題解決を促 す有効なツールと考えられる。

プレゼンテーションではe-learningコンテンツ 作成システムを活用し, パワーポイント資料と 発表者の表情を同時に記録した。このような発表 の場を設定することにより, 生徒は事前に発表原 稿をきちんと準備し, 発表内容の整理を効果的に 行う必要を感じたと考えられる。資料作成の事前 指導で，発表内容のストーリーを考えることと， プレゼンテーションのまとめを作って，わかった ことを整理することを強調したため, 地図を表示 するだけの発表に陥ることなく，高校生としては 高度な成果発表に繋がったのではないかと思われ る。

3 日間の講座終了後の生徒の感想では,「GIS のソフトをきちんと使いこなせるようになること
はとても大切だが，それ以上に自分なりの仮説を もって探求することや, 新しい切り口をもって積 極的に挑んでいくこと等が大切だと思った」とい うことや，「GISをすごいと思ったことは，その ままでは単なるデー夕の塊であったものが, 地 図に対応させることで，『デー夕』と『地図』と の関係だけでなく, 『デー夕』相互間の関係まで もみえ，それが意味をもったものになっていくこ とだと思った」ということが述べられた。そのた め当初の目標であった課題発見, 課題解決の思考 を，GISというツールを用いることで養うことが できたと考える。

\section{IV . 展望と課題}

GISを活用した小・中・高校の地理学習や大学 に扮ける地理学実習の実践は非常に多く, 野外調 查におけるGIS活用，GISによる主題図作成，GIS を活用した空間分析などが行われている。また， 海水面温度の上昇变化やインナーシティ問題と再 開発など，現行の地理の教育課程の内容をGISの 実習に取り入れて，「地理的見方・考え方」を深 化させる効果をねらう事例もみられる。

しかし，実践にあたっては，GISソフトのもつ 様々な機能を生徒が使いこなせるだけの技量を習 得するための実習の必要性という, 本来の目的以 外にさかれる時間および労力の膨大さが, 指導者 にGIS教育を積極的に進めることを躊躇させるこ とにつながっているのではないかと考えられる。

本実践では，単に「GISを活用する」だけにと どまらず，分析対象を明確にし，GISで分析する 際に必要とする機能を精選することによって, GISが育成可能である空間認識能力, 課題発見能 力, 課題解決能力の育成に貢献することを示すこ とに成功したのではないかと考える。地理空間情 報の整備が進み，それらを効果的に活用して，ど のようにより良い社会を構築するべきかについて 考察することは, 中等教育段階で今後特に力を入 れて取り組まなければならないであろう。本実践 では，そのための中等教育段階における地理空間 情報の活用の事例を示すことができたと思う。

しかし，本事業でArcViewを高等学校の環境 に導入するに当たっては，困難が生じたことも 指摘したい。本校のコンピュータ教室の運営に 
あたっては, 生徒のコンピュータの活用状況や 指導の統括を行うSKY MENUというICT支援ソ フトウェアが, すべての生徒用コンピュータに 導入されている。このSKY MENUがインストー ルされていると, ArcViewのインストールがで きないという不具合があるため, 通常授業の際 の運用とは違う特殊な設定によって, 今回の実 習期間のみArcViewをインストールした。本校 のコンピュータ教室のパソコンの運用にあたり SKY MENUを外すことができないため, 残念な がら，実践が終わった現在ではArcViewはアン インストールされている。GISに興味をもった生 徒も，本実習の期間だけしか触れることができな かったということになる。SKY MENUは, ほと んどの高等学校で活用されているソフトウェアで あり，そこではArcViewなどGISソフトの導入が 極めて困難な状況にある。GISを高等学校に導入 するにあたって，このような基本的な障害が除か れることを願ってやまない。

\section{謝辞}

本実践の実施にあたり, 北海道大学大学院文学研究科の 橋本雄一准教授のご指導やご助言をいただいた。また, 講 座期間中のGIS操作の指導においては, 北海道大学大学院 文学研究科博士課程の川村真也氏の協力を受けた。北海道 大学大学院文学研究科 大学院教育改革支援プログラムの 関係者の方々にはe-learningシステムを貸し出していただ いた。SPP事業実施に関して, 北海道札幌北高等学校高大 連携委員会の宮嶋衛次教頭, JST (独立行政法人科学技術 振興機構) 理数学習支援部連携学習支援課SPP事務局担当 片山氏をはじめとする方々のご助言，ご協力を得た。GIS ソフトウェア導入及びインストールにあたっては, 株式会 社GIS北海道 小西 将史氏, 北ガスサービス株式会社の 方々, ESRIジャパン株式会社 矢口 浩平氏, 北海道札 幌北高等学校教諭 奥村 稔氏, 日比 誠氏, 北海道稲北 高等学校教諭 加藤 誠氏のご助言, ご協力を受けた。以 上，記して感謝いたします。 